\title{
Antimanic drug sensitizes breast cancer cell line to ionizing radiation
}

\author{
Maryam Rouhani ${ }^{1}$, Bahram Goliaei ${ }^{1}$, Fariba Khodagholi ${ }^{2}$ and Alireza Nikoofar ${ }^{3}$ \\ ${ }^{1}$ Laboratory of Biophysics and Molecular Biology, Institute of Biochemistry and Biophysics, University of Tehran, Tehran, Iran \\ ${ }^{2}$ NeuroBiology Research Center, Shahid Beheshti University of Medical Sciences, Tehran, Iran \\ ${ }^{3}$ Department of Radiotherapy, Firoozgar Hospital, Iran University of Medical Sciences, Tehran, Iran
}

\begin{abstract}
Breast cancer is one of the most prevalent types of cancer among women. Lithium chloride $(\mathrm{LiCl})$ is an FDA-approved drug for bipolar disorder. Breast cancer is reported to occur with higher rate in women with bipolar disorder. The effect of $\mathrm{LiCl}$ on the response of breast cancer cells to ionizing radiation has not been studied. We studied the effect of $\mathrm{LiCl}$ on the radiosensitivity of radioresistant T47D breast cancer cell line. Treatment of T47D cells with $20 \mathrm{mM} \mathrm{LiCl}$ for 24 hours decreased the radioresistance of these cells indicated by clonogenic survival assay. Comet assay demonstrated decreased DNA repair in LiCl-treated cells. LiCl treatment also decreased the meiotic recombination 11 (Mre11) mRNA level. Mre11 is an essential protein for DNA repair whose transcription is regulated by $\beta$-catenin protein. Western blot analysis indicated that the $\beta$-catenin protein level was decreased

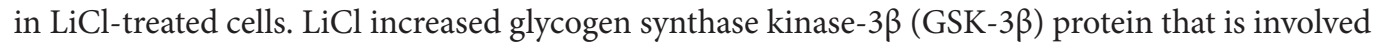
in $\beta$-catenin degradation. The results demonstrated that $\mathrm{LiCl}$ could radiosensitize T47D cells by decreasing DNA repair, partially through Mre11 repression. GSK-3 $\beta / \beta$-catenin/Mre11 pathway might be the connection between $\mathrm{LiCl}$ treatment and the decreased DNA repair in T47D cells.
\end{abstract}

Key words: $\mathrm{LiCl}-\mathrm{T} 47 \mathrm{D}-$ Radiosensitivity - DNA repair - Mre11

Abbreviations: DSB, double strand break; GSK-3 3 , glycogen synthase kinase- $3 \beta ;$ HRR, homologous recombination repair; IR, ionizing radiation; $L Q$, linear-quadratic; Mre11, meiotic recombination 11; MRN, Mre11/Rad50/Nbs1; \%T, percent DNA in tail; TLK, two-lesion kinetic.

\section{Introduction}

Breast cancer is one of the most common and life-threatening types of cancers in women worldwide (Dumitrescu and Cotarla 2005). Eradicating tumor cells by ionizing radiation (IR) is an efficient approach in breast cancer therapy. Yet, sensitizing radioresistant breast cancer cells to IR is a challenge in cancer radiotherapy. T47D is an epithelial human breast cancer cell line obtained from metastatic sites of a patient with ductal carcinoma. This cell line is a radioresistant human breast cancer cell line (Siles et al. 1996; Coco Martin et al. 1999).

Lithium is an antimanic drug used for treatment of bipolar disorder (Quiroz et al. 2004). Breast cancer occurrence

Correspondence to: Bahram Goliaei, Laboratory of Biophysics and Molecular Biology, Institute of Biochemistry and Biophysics, University of Tehran, P.O.Box 13145-1384, Tehran, Iran E-mail: goliaei@ibb.ut.ac.ir is higher in women with bipolar disorder (BarChana et al. 2008; McGinty et al. 2012). Lithium chloride (LiCl) has been shown to have antiproliferative and apoptotic effects in some breast cancer cell lines (Gustin et al. 2009; Higgins et al. 2011; Kaufmann et al. 2011). There are a few reports about the effect of $\mathrm{LiCl}$ on radioresistance and double strand break (DSB) repair in cancer cells (Yazlovitskaya et al. 2006; Yang et al. 2009). However, these effects have not been studied in breast cancer cells.

IR induces lethality mainly by induction of DSBs in DNA molecules. Tumor cells are more proficient in DNA DSB repair and therefore are more resistant to IR (Ding et al. 2006). Hence, targeting DSB repair pathways would be a beneficial strategy for overcoming radioresistance of cancer cells (Ding et al. 2006). The meiotic recombination 11 (Mre11) is a key protein of the mammalian three-component complex Mre11/Rad50/Nbs1 (MRN). This complex is pivotal for DSB recognition and repair (Stracker and Petrini 2011). Mre11 mutation results in ATLD (ataxia-telangiectasia-like dis- 
order) accompanied with high sensitivity to IR (Stewart et al. 1999). It is demonstrated that Mre11 is a key protein for targeting DSB repair and increasing tumor radiosensitivity (Deng et al. 2011; Yuan et al. 2012). We have studied the effect of $\mathrm{LiCl}$ on the radiosensitivity, DNA repair and Mre11 expression in T47D breast cancer cell line. This is the first study about the relationship between $\mathrm{LiCl}$ treatment and Mre11 expression.

\section{Materials and Methods}

All chemicals were purchased from Merck unless otherwise mentioned.

\section{Cell culture and treatments}

The T47D breast cancer cell line was obtained from National Cell Bank of Iran (NCBI)-Pasteur Institute of Iran. Cells were maintained in RPMI-1640 medium (Gibco) in 10\% FBS (Gibco) containing streptomycin and penicillin (Sigma) antibiotics and incubated at $37^{\circ} \mathrm{C}$ in a humidified atmosphere with $5 \% \mathrm{CO}_{2}$. Cells were plated at $2 \times 10^{4} \mathrm{cells} / \mathrm{cm}^{2}$ density. After three days, cells were treated with $\mathrm{LiCl}$ ( 0 or $20 \mathrm{mM}$ ) for 24 hours. Radiation was performed by a linear accelerator X-ray machine (Siemens Primus) at $2 \mathrm{~Gy} / \mathrm{min}$ dose rate and $6 \mathrm{MV}$ energy. The $20 \mathrm{mM} \mathrm{LiCl}$ concentration was a non-toxic concentration (Fig. S1) that did not induce DNA break (Fig. S2).

\section{Clonogenic survival assay}

LiCl-treated and control cells were exposed to 2, 3, and 6 Gy of IR or mock-irradiated. Cells were plated in triplicates in $60 \mathrm{~mm}$ plates in suitable densities. After 13 days of incubation, colonies were fixed with formaldehyde and stained with crystal violet. Colonies containing more than 50 cells were counted. Surviving fractions were calculated by dividing the number of counted colonies to the expected number of colonies. Changes in surviving fractions were indicator of variation in radiosensitivity. These survival curves were fitted to the linear-quadratic (LQ) model by the OriginPro8 software (Barendsen 1992).

We also analyzed the clonogenic survival data using the two-lesion kinetic (TLK) model by virtual cell radiobiology software (VC 2.00A) provided by Dr. Robert D. Stewart (Department of Radiation Oncology, University of Washington). The virtual cell input parameters were set to find the most reliable results based on the least function of merit (FOM) score. In TLK model a simple DSB refers to a 10-20 bp section of DNA that contains one break in each strand. A complex DSB contains additional defects including base damage, strand break and base deletion. The repair rate of simple and complex DSBs is $\lambda_{1}$ and $\lambda_{2}$ respectively. The probability of a misrepair to be lethal is denoted by $\varphi$. Besides, two DSBs can interact with the rate $\eta$ (Stewart 2001; Guerrero et al. 2002).

\section{Alkaline comet assay}

LiCl-treated and control cells were exposed to 3 Gy of IR or mock-irradiated. Cells were incubated for 15 or $45 \mathrm{~min}$ at $37^{\circ} \mathrm{C}$ before performing comet assay. About $2 \times 10^{4}$ cells were mounted within $0.5 \%$ low melting point agarose (Sigma) on slides previously coated with $1 \%$ agarose. The alkaline comet assay was carried out as described previously (Singh et al. 1988). Briefly, slides were incubated in lysis buffer (2.5 M NaCl, 100 mM EDTA, 10 mM Tris-HCl, and $1 \%$ Triton $\mathrm{X}-100 ; \mathrm{pH} 10)$ for 1 hour. Denaturation buffer (300 mM NaOH, 1 mM EDTA; pH 13) was added on slides for $30 \mathrm{~min}$. Slides were electrophoresed at $1 \mathrm{~V} / \mathrm{cm}$ within fresh denaturation buffer for $30 \mathrm{~min}$. Neutralization buffer (400 mM Tris-HCl; pH 7.5) was added on slides for about $5 \mathrm{~min}$. All these stages were performed at $4^{\circ} \mathrm{C}$. Cells were stained with Ethidium Bromide and observed under a fluorescence microscope (Zeiss, Axioskop 2 plus).

At least 200 cells were analyzed by CometScore freeware (version 1.5; TriTek Corp.). Percent DNA in tail (\%T) was utilized as an indicator of the amount of DNA damage (Kumaravel and Jha 2006). To omit the effect of time and treatment, we calculated the "IR-induced \%T" as: \% T of irradiated cells - \% $\mathrm{T}$ of unirradiated similarly treated cells at the same time point.

\section{Western blot analysis}

Total cell extracts were obtained by scraping cells in lysis buffer (200 mM NaCl, 2\% w/v SDS, 50 mM Tris-HCl, 2 mM EDTA, 5 mM DTT, and 1 mM PMSF; pH 8). SDS-PAGE was performed and proteins were blotted on PVDF membranes (BioRad). Antibodies against GSK-3 $\beta$ and Lamin B2 were obtained from Cell Signaling Technology and Santa Cruz Biotechnology, respectively. The antibody against $\beta$-catenin was kindly gifted by Dr. S. Mahmoud A. Najafi (Department of Cell \& Molecular Biology, Faculty of Biology, University of Tehran) (Salmanian et al. 2010). Protein bands were detected using enhanced chemiluminescence kit (Amersham Bioscience). Bands were analyzed by TotalLab software.

\section{Semi-quantitative reverse transcription-polymerase chain reaction ( $R T-P C R)$}

RNA was extracted by High Pure RNA Isolation Kit (Roche) based on manufacturer's protocol. RT-PCR was performed by Thermo Hybrid PCR machine using 2-steps RT-PCR Kit (vivantis). We designed Mre11 primers (Forward: 5'-ggcaat- 
catgacgatcccaca-3', Reverse: 5'-tgttcatggccccagataacaa-3') by Primer3 software (Ye et al. 2012) to amplify a 362 bp fragment located within exons 5 to 8 . $\beta$-actin mRNA was amplified as the internal control using previously designed primer set (Forward: 5'-GGCGGCACCACCATGTACCCT3', Reverse: 5'-AGGGGCCGGACTCGTCATACT-3') that gives a 202 bp PCR product (Lango et al. 2002). Bands were analyzed by TotalLab software.

\section{Statistical analysis}

All results were reported as mean \pm SEM (standard error of mean) of three independent experiments. The statistical significance of clonogenic and comet assay data was checked with Two-Way repeated mode ANOVA followed by post hoc Tukey analysis. The One-Way repeated mode ANOVA followed by post hoc Tukey analysis was used to check the significance of the Western blot and RT-PCR data. The statistical analyses were performed by the OriginPro8 software. A $p$ value less than 0.05 was considered significant.

\section{Results}

\section{The effect of LiCl on the radiosensitivity of T47D cell line}

Based on post hoc Tukey test, at 0.05 significance level, the samples treated with lithium had significantly lower surviving fractions after exposure to radiation when compared to samples in regular medium (Fig. 1). Pairwise comparison Tukey analysis revealed significant differences between surviving fractions of control and LiCl-treated cells at all doses of X-ray $(p<0.01)$. Clonogenic survival curve was fitted to the LQ model. $\alpha, \beta$ and SF2 (surviving fraction at 2 Gy) parameters of the LQ model are summarized in Table 1. LiCl treatment induced a 2.7-fold increase in the $\alpha$ parameter and sensitized the cells even at low doses of ionizing radiation.

Effect of LiCl pretreatment on the repair of IR-induced DNA damages

Alkaline comet assay was performed to determine the effect of $\mathrm{LiCl}$ on DNA repair in irradiated cells. Percent DNA in tail (\%T) was measured in control and LiCl-treated cells mock-irradiated or irradiated with 3 Gy of X-ray (Fig. 2A). The "IR-induced \% T" was calculated as described in Materials and Methods (Fig. 2B). LiCl did not induce any DNA damage in unirradiated cells (Fig. 2A, S2). However, based on Two-Way repeated mode ANOVA followed by post hoc Tukey analysis $\mathrm{LiCl}$ treatment significantly increased the "IR-induced \% T" at $15(p<0.01)$ and $45(p<0.001)$ min post-IR (Fig. 2B).

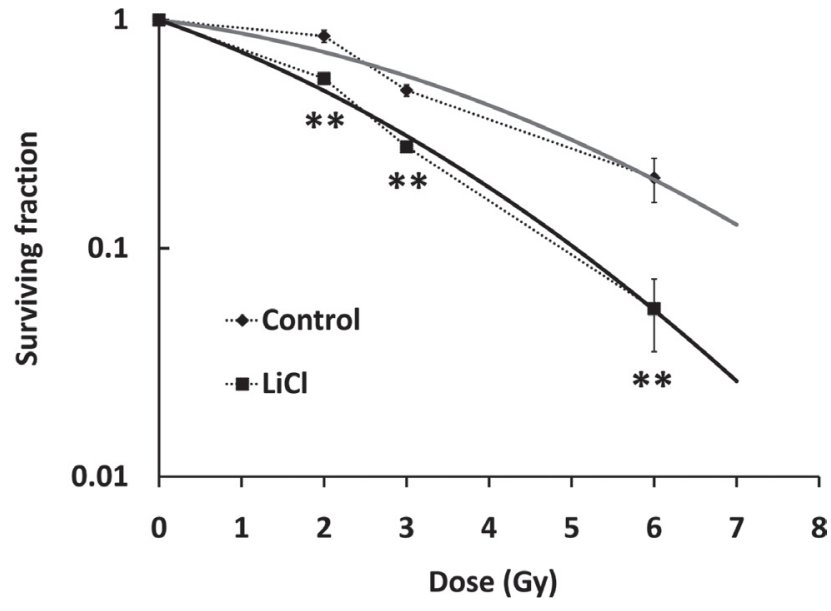

Figure 1. LiCl decreased the radioresistance of T47D cells. Clonogenic survival assay was performed for control cells and cells treated with $\mathrm{LiCl}(20 \mathrm{mM})$ for 24 hours before exposure to different doses of X-ray. Data represent mean \pm SEM of three independent experiments. Solid lines are the LQ model fits. ${ }^{* *} p<0.01$ compared with control.

During the chased period (30 min), $81 \%$ of "IR-induced $\% \mathrm{~T}$ " faded in control cells $(p<0.001)$. However, this feature was $33 \%$ for LiCl-treated cells $(p<0.01)$ (Fig. 2B). Therefore, $\mathrm{LiCl}$ decreased the repair rate of IR-induced DNA damages.

To estimate the kinetics parameters of DNA repair, we analyzed clonogenic survival data with the TLK DSB repair model (Stewart 2001; Guerrero et al. 2002). Parameters that were different between control and LiCl-treated cells are summarized in Table 2 . LiCl treatment induced a 4.5 -fold

Table 1. Parameters obtained from fitting clonogenic survival data to the LQ model

\begin{tabular}{lccc}
\hline & $\alpha(1 / \mathrm{Gy})$ & $\beta\left(1 / \mathrm{Gy}^{2}\right)$ & $\mathrm{SF} 2$ \\
\hline Control & 0.11 & 0.027 & 0.72 \\
$\mathrm{LiCl}$ & 0.29 & 0.033 & 0.49 \\
\hline
\end{tabular}

$\mathrm{SF}$, surviving fraction at $2 \mathrm{~Gy}$.

Table 2. Parameters obtained from fitting clonogenic survival data to the TLK model

\begin{tabular}{lcccc}
\hline & $\lambda_{1}(1 / \mathrm{h})$ & $\lambda_{2}(1 / \mathrm{h})$ & $\varphi$ & $\eta(1 / \mathrm{h})$ \\
\hline Control & 69.3 & 0.10 & 0.011 & 0.0014 \\
LiCl & 69.3 & 0.03 & 0.049 & 0.0006 \\
\hline
\end{tabular}

$\lambda_{1}$, simple DSB repair rate; $\lambda_{2}$, complex DSB repair rate; $\varphi$, the probability of a misrepair to be lethal; $\eta$, DSB-DSB pairwise interaction rate. 
increase in the $\varphi$ parameter (the probability that misrepaired DSB is lethal). According to the TLK model outputs, $\mathrm{LiCl}$ decreased the repair rate of complex DSBs $\left(\lambda_{2}\right)$ and the rate of DSB-DSB interaction $(\eta)$ by 3.6- and 2.3-folds, respectively.

\section{Alterations in GSK-3 $\beta$ and $\beta$-catenin protein levels and} Mre $11 \mathrm{mRNA}$ level in response to LiCl treatment

We evaluated total GSK-3 $\beta$ protein level in control and LiCl-treated T47D cells by Western blot analysis (Fig. 3). Treatment of T47D cells with 10 and $20 \mathrm{mM}$ of LiCl in-

A
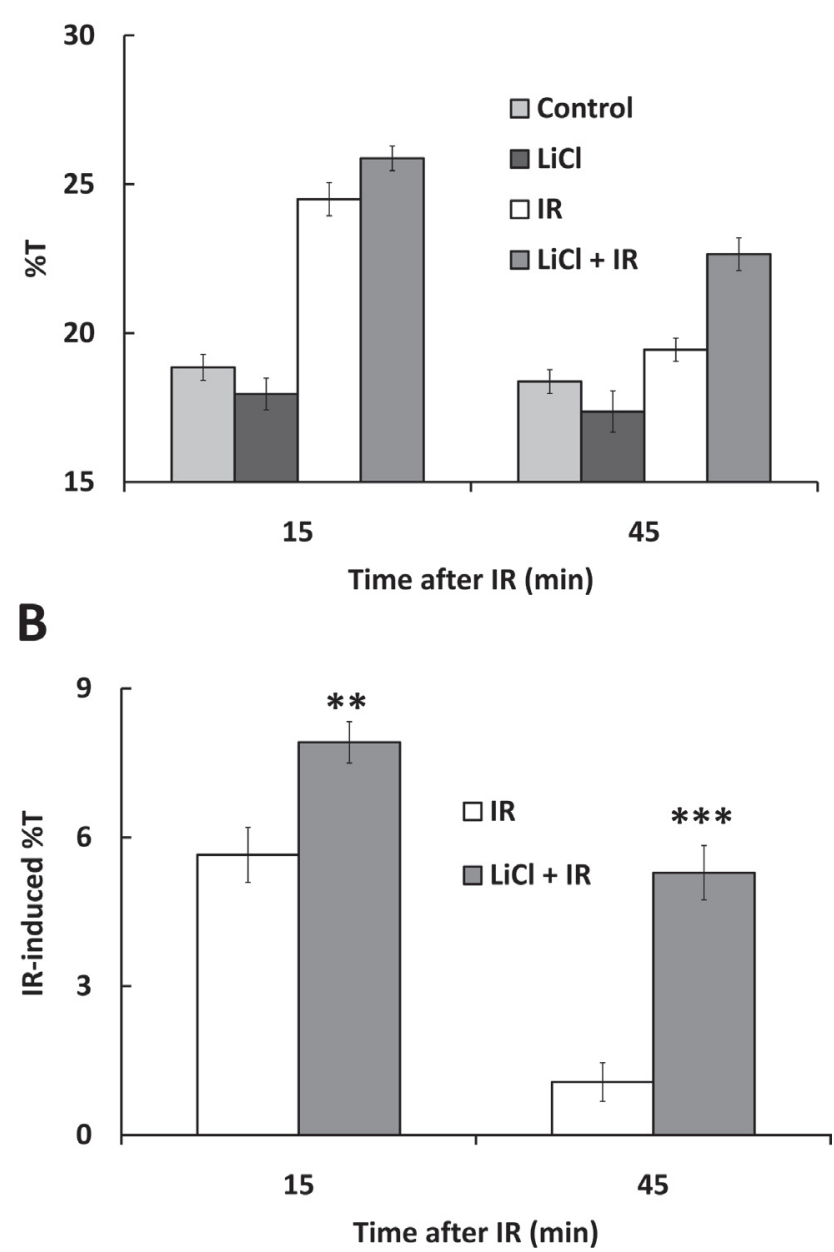

Figure 2. $\mathrm{LiCl}$ hindered the repair of IR-induced DNA damages in T47D cell line. Control and $\mathrm{LiCl}(20 \mathrm{mM})$-treated cells were subjected to alkaline comet assay at 15 and $45 \mathrm{~min}$ after exposure to 0 or 3 Gy of X-ray. Percent DNA in tail (\%T) (A) and "IR-induced $\% \mathrm{~T}$ " $(\mathbf{B})$ are depicted at both time points. Data represent mean \pm SEM of three independent experiments. ${ }^{* *} p<0.01,{ }^{* * *} p<0.001$ compared with control irradiated cells.
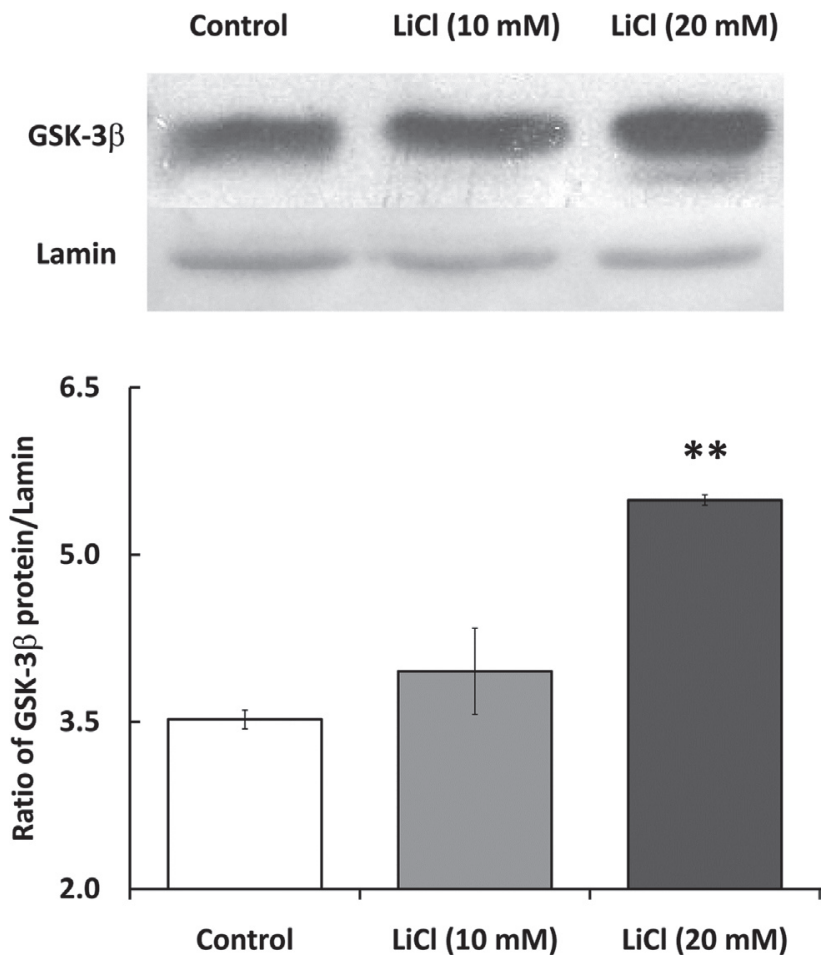

Figure 3. $\mathrm{LiCl}$ treatment increased the total level of GSK-3 $\beta$ protein. GSK-3 $\beta$ level was determined by immunoblotting in lysates of control cells and cells treated with $10 \mathrm{mM}$ and $20 \mathrm{mM} \mathrm{LiCl}$ for 24 hours. Lamin B2 was used as the loading control. Data represent mean \pm SEM of three independent experiments. ${ }^{* *} p<0.01$ compared with control.

creased GSK-3 $\beta$ protein level by 12 and 56\% $(p<0.01)$, respectively.

We assessed $\beta$-catenin protein and Mre11 mRNA levels in control and LiCl-treated T47D cells (Fig. 4). Western blot analysis indicated a $17 \%$ decrease in the amount of $\beta$-catenin protein in cells treated with $\mathrm{LiCl}(20 \mathrm{mM})(p<0.05)$ (Fig. $4 \mathrm{~A})$. On the other hand, RT-PCR analysis revealed a $20 \%$ decrease in Mre11 mRNA level in cells treated with $\mathrm{LiCl}$ $(20 \mathrm{mM})(p<0.05)$ (Fig. 4B).

\section{Discussion}

We have demonstrated the radiosensitization effect of $\mathrm{LiCl}$, as a common antimanic drug, on the radioresistant T47D breast cancer cell line. Treatment of these cells with $\mathrm{LiCl}$ suppressed DNA repair after exposure to IR. $\mathrm{LiCl}$ decreased the Mre 11 expression involved in DSB repair processes. Alterations in GSK-3 $\beta / \beta$-catenin/Mre11 pathway components were in accordance with the decreased DNA repair and increased radiosensitivity in LiCl-treated T47D cells. 
Although LiCl did not induce DNA damage in unirradiated cells, it predisposed T47D cells to higher DNA damage at 15 and 45 min post-IR (Fig. 2A). The repair of DNA damage was slower in T47D cells treated with $\mathrm{LiCl}$ compared with control untreated cells (Fig. 2B). The lower repair rate in LiCl-treated cells might underlie the higher radiosensitivity of these cells observed in clonogenic survival assay.

We observed higher GSK-3 $\beta$ and lower $\beta$-catenin protein levels in LiCl-treated T47D cells. Although $\mathrm{LiCl}$ is known as an inhibitor of GSK-3 $\beta$ protein (Quiroz et al. 2004), it increased total level and decreased the inactive form of GSK$3 \beta$ in some breast cancer cells (Gustin et al. 2009). It was mentioned that the $\mathrm{LiCl}$-induced increase in GSK-3 $\beta$ protein level occurred through an unknown mechanism. GSK-3 $\beta$ phosphorylates and thereby targets $\beta$-catenin molecule for proteasomal degradation (Liu et al. 2002). Therefore, the decreased $\beta$-catenin protein level (Fig. $4 \mathrm{~A}$ ) verified the functionality of upregulated GSK- $3 \beta$. GSK- $3 \beta / \beta$-catenin pathway might play an important role in $\mathrm{LiCl}$-induced alterations in radioresistance of breast cancer cell lines. It is also possible that $\mathrm{LiCl}$ inhibits DSB repair by affecting other LiCl targets (Quiroz et al. 2004).

A
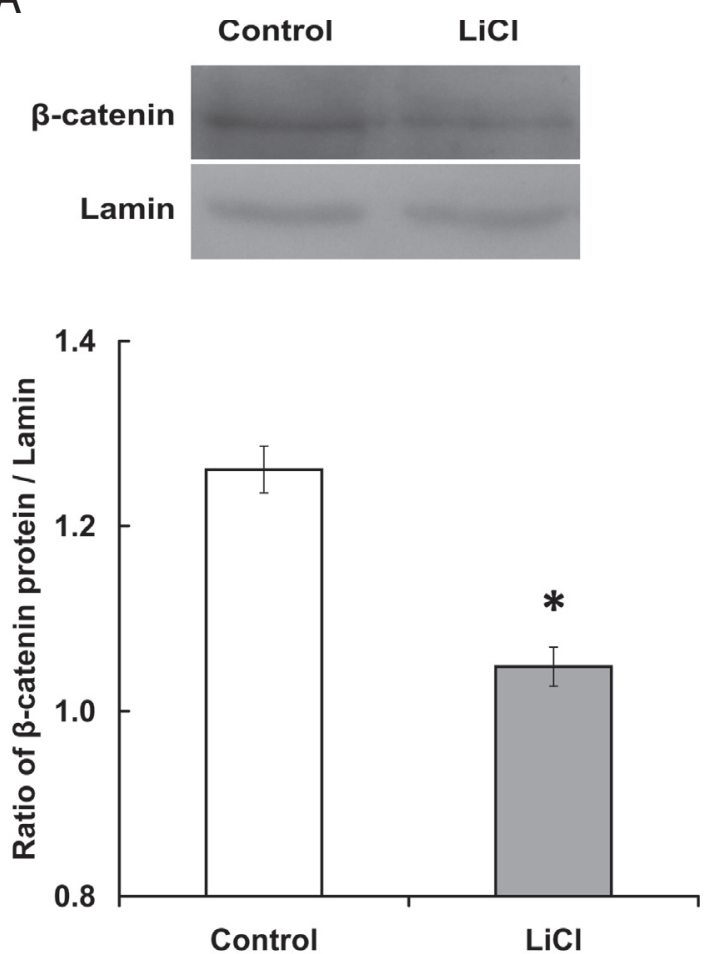

$\mathrm{LiCl}$ treatment decreased the Mre11 mRNA level in T47D cells (Fig. 4B). It is mentioned that a direct correlation exists between Mre11 mRNA and its protein level (Garner and Eastman 2011). The Mre11 repression was accompanied by decrease in $\beta$-catenin protein level. $\beta$-catenin protein level has been shown to be in direct correlation with Mre11 transcription (Deng et al. 2011).

Based on the estimated results of TLK model, LiCl decreased the complex DSB repair rate $\left(\lambda_{2}\right)$ and the DSB-DSB pairwise interaction rate $(\eta)$ but it did not change the simple DSB repair rate $\left(\lambda_{1}\right)$. The $\lambda_{2}$ and $\eta$ lower repair rates in LiCltreated cells could increase the remaining DSBs as observed in comet assay experiments (Fig. 2B). Among the IR-induced DNA lesions, DSBs are the most lethal. Two major DSB repair pathways are non-homologous end joining (NHEJ) and homologous recombination repair (HRR). NHEJ repair is subdivided into canonical NHEJ (C-NHEJ) and alternative end joining (A-EJ). Mre11 is one of the three components of the MRN complex involved in the C-NHEJ repair of complex DSBs (Huang and Dynan 2002; Riballo et al. 2004). Simple DSBs that undergo fast repair (Stewart 2001; Reynolds et al. 2012) need Ku70/80 and ligase IV/XRCC4 complexes and

B
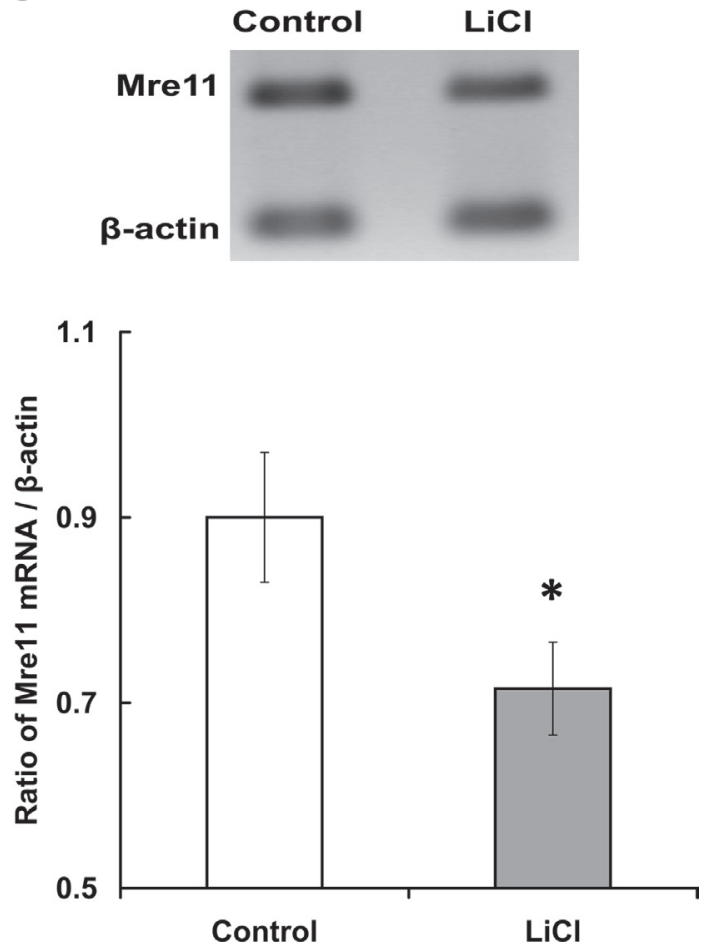

Figure 4. LiCl treatment decreased $\beta$-catenin protein and Mre11 mRNA levels. Lysates of control cells and cells treated with $20 \mathrm{mM}$ $\mathrm{LiCl}$ for 24 hours were used for assessing $\beta$-catenin protein level by immunoblotting (A) and Mre11 mRNA level by RT-PCR analysis (B). Lamin B2 and $\beta$-actin were used as loading controls. Data represent mean \pm SEM of three independent experiments. ${ }^{\star} p<0.05$ compared with control. 
probably are not dependent on MRN for their repair process (Yamaguchi-Iwai et al. 1999; Reynolds et al. 2012). MRN complex is also involved in HRR (Limbo et al. 2007; Stracker and Petrini 2011) and A-EJ (Rass et al. 2009; Xie et al. 2009) via the end resection process. Consequently, MRN is essential for processing complex DSBs. Mre11 down-regulation leads to a decreased number of MRN complexes (Takemura et al. 2006). Therefore, decrease in Mre11 level slows down the repair of complex DSBs either when ends to be joined belong to one DSB or to two interacting DSBs.

The TLK model also predicted a 4.5 -fold increase in the $\varphi$ parameter (the probability that misrepaired DSB is lethal) in LiCl-treated T47D cells. This increase in lethality was consistent with the decreased survival in LiCl-treated cells (Fig. 1). The MRN complex localizes at DSBs soon after radiation (Haince et al. 2008). This complex is involved in tethering DSB ends together or to the template chromatid during HRR (Williams et al. 2008). Therefore, Mre11 downregulation might decrease the available linker complexes at the time of radiation. Hence, there would be some free DSB ends that may move about and juxtapose other free ends or template sequences. These ends might be recognized by MRN complex later and linked and repaired erroneously. Misrepaired DSBs can cause chromosomal aberrations and increase cell lethality.

MRN complex also participates in initiating signaling pathways that lead to checkpoint activation (D'Amours and Jackson 2002; Carson et al. 2003; Difilippantonio et al. 2007). Therefore Mre11 repression hinders cell cycle arrest and decreases the available time for repairing DSBs. The decreased repair rate and repair opportunity due to Mre11 deficiency leads to the accumulation of DSBs as observed previously (Costanzo et al. 2001). DSB accumulation along with higher amount of chromosomal aberrations increases cell lethality and IR sensitivity in Mre11 deficient cells. Therefore, the observed Mre11 repression in LiCl-treated T47D cells was in agreement with TLK model-derived parameters. Because Mre11 is significant for DSB repair, the observed Mre11 repression might be an important reason for DNA break repair defect and lower clonogenic survival in LiCl-treated T47D cells.

We suggested $\mathrm{LiCl}$ as a radiosensitizer capable of decreasing Mre11 expression in radioresistant T47D breast cancer cell line. We also proposed a molecular pathway that links $\mathrm{LiCl}$ treatment to the decrease in DNA repair and the relationship between $\mathrm{LiCl}$ and $\mathrm{Mre} 11$ repression. $\mathrm{LiCl}$ down-regulates Mre11 expression possibly through GSK$3 \beta / \beta$-catenin pathway. $\mathrm{LiCl}$ increased the radiosensitivity of T47D breast cancer cell line by decreasing Mre 11 expression involved in DSB repair processes.

The findings of this study must be viewed in light of its limitations. Firstly, in this study the alkaline comet assay was used to measure the amount of both single and double strand breaks. Changes in the amount of double strand breaks can be determined by more specific assays. Secondly, the possible involvement of other molecular pathways in LiCl-induced radiosensitization can not be ruled out. Specific siRNAmediated downregulation of GSK-3 $\beta$ together with $\mathrm{LiCl}$ treatment can clarify to what extent the GSK-3 $\beta$ protein is involved in the $\mathrm{LiCl}$-induced radiosensitization. On the other hand, overexpression of $\beta$-catenin or Mre11 together with $\mathrm{LiCl}$ treatment can certify the involvement of these proteins in the sensitization induced by $\mathrm{LiCl}$.

In the current study, $\mathrm{LiCl}$ was indicated to decrease the radioresistance of a breast cancer cell line. This radiosensitization was apparent even at therapeutic doses of ionizing radiation. Further work is necessary to investigate the effect of $\mathrm{LiCl}$ on other breast cancer cells. In vivo studies would further clarify the effect of $\mathrm{LiCl}$ on the response of breast tumors to ionizing radiation. Eventually $\mathrm{LiCl}$ might be used in combination with radiotherapy for eradicating breast tumors.

Acknowledgement. This work was financially supported by the Research Council of the University of Tehran.

\section{Supplementary Figures}

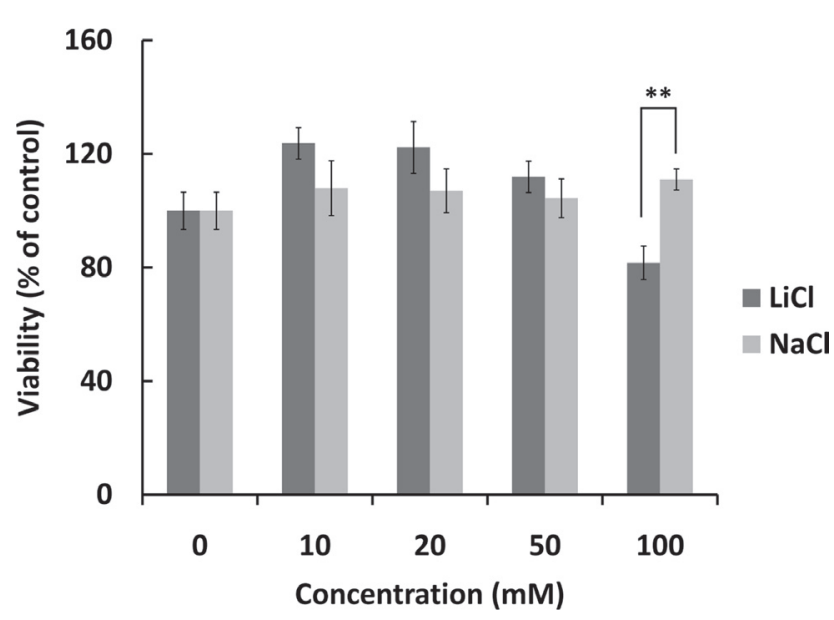

Figure S1. LiCl did not decrease cell viability up to $50 \mathrm{mM}$ concentration. Cells were treated with $0,10,20,50$ and $100 \mathrm{mM}$ concentrations of $\mathrm{NaCl}$ (as control salt) or $\mathrm{LiCl}$ for 24 hours and viability was determined by MTT assay (Mosmann 1983). Briefly, $50 \mu \mathrm{l}$ MTT solution $(2 \mathrm{mg} / \mathrm{ml})$ was added to each well. Cells were incubated at $37^{\circ} \mathrm{C}$ for 3 hours. $100 \mu \mathrm{l}$ dimethyl sulfoxide was added to each well. Absorbance was determined at 540 and $630 \mathrm{~nm}$ wavelengths using BioTek plate reader. The differences between these two absorbances were used for determining viability. The viability was set to $100 \%$ for cells without any treatment. Data represent mean \pm SEM of three independent experiments. ${ }^{* *} p<0.01$ compared with $\mathrm{NaCl}$-treated cells based on Two-Way repeated mode ANOVA followed by post hoc Tukey analysis. 


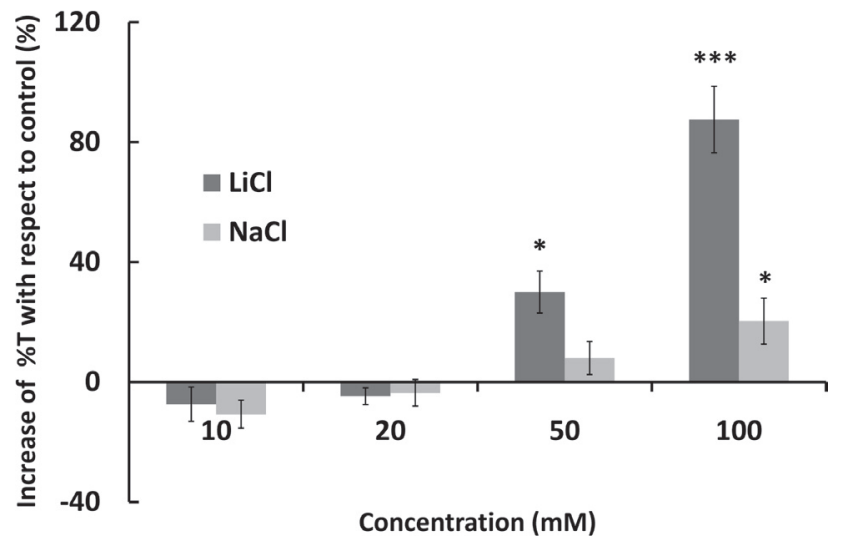

Figure S2. LiCl did not induce DNA break up to $20 \mathrm{mM}$ concentration. Alkaline comet assay was performed on control cells and cells treated with different concentrations of $\mathrm{LiCl}$ and $\mathrm{NaCl}$ for 24 hours as described in Materials and Methods. Data represent mean \pm SEM of three independent experiments. ${ }^{*} p<0.05,{ }^{* * *} p<0.001$ compared with control cells based on Two-Way repeated mode ANOVA followed by post hoc Tukey analysis.

\section{References}

BarChana M., Levav I., Lipshitz I., Pugachova I., Kohn R., Weizman A., Grinshpoon A. (2008): Enhanced cancer risk among patients with bipolar disorder. J. Affect. Disord. 108, 43-48 http://dx.doi.org/10.1016/j.jad.2007.09.003

Barendsen G. W. (1992): Radiation-induced DNA damage in relation to linear and quadratic terms of dose-effect relationships for cell reproductive death. BJR Suppl. 24, 53-56

Carson C. T., Schwartz R. A., Stracker T. H., Lilley C. E., Lee D. V., Weitzman M. D. (2003): The Mre11 complex is required for ATM activation and the G2/M checkpoint. EMBO J. 22, 6610-6620 http://dx.doi.org/10.1093/emboj/cdg630

Coco Martin J. M., Mooren E., Ottenheim C., Burrill W., Nunez M. I., Sprong D., Bartelink H., Begg A. C. (1999): Potential of radiation-induced chromosome aberrations to predict radiosensitivity in human tumour cells. Int. J. Radiat. Biol. $75,1161-1168$ http://dx.doi.org/10.1080/095530099139638

Costanzo V., Robertson K., Bibikova M., Kim E., Grieco D., Gottesman M., Carroll D., Gautier J. (2001): Mre11 protein complex prevents double-strand break accumulation during chromosomal DNA replication. Mol. Cell 8, 137-147 http://dx.doi.org/10.1016/S1097-2765(01)00294-5

D'Amours D., Jackson S. P. (2002): The Mre11 complex: at the crossroads of dna repair and checkpoint signalling. Nat. Rev. Mol. Cell Biol. 3, 317-327 http://dx.doi.org/10.1038/nrm805

Deng R., Tang J., Ma J. G., Chen S. P., Xia L. P., Zhou W. J., Li D. D., Feng G. K., Zeng Y. X., Zhu X. F. (2011): PKB/Akt promotes DSB repair in cancer cells through upregulating Mre11 expression following ionizing radiation. Oncogene 30, 944-955 http://dx.doi.org/10.1038/onc.2010.467

Difilippantonio S., Celeste A., Kruhlak M. J., Lee Y., Difilippantonio M. J., Feigenbaum L., Jackson S. P., McKinnon P. J., Nussenzweig A. (2007): Distinct domains in Nbs1 regulate irradiation-induced checkpoints and apoptosis. J. Exp. Med. 204, 1003-1011 http://dx.doi.org/10.1084/jem.20070319

Ding J., Miao Z. H., Meng L. H., Geng M. Y. (2006): Emerging cancer therapeutic opportunities target DNA-repair systems. Trends Pharmacol. Sci. 27, 338-344 http://dx.doi.org/10.1016/j.tips.2006.04.007

Dumitrescu R. G., Cotarla I. (2005): Understanding breast cancer risk -- where do we stand in 2005? J. Cell Mol. Med. 9, 208-221 http://dx.doi.org/10.1111/j.1582-4934.2005.tb00350.x

Garner K. M., Eastman A. (2011): Variations in Mre11/Rad50/Nbs1 status and DNA damage-induced S-phase arrest in the cell lines of the NCI60 panel. BMC Cancer 11, 206 http://dx.doi.org/10.1186/1471-2407-11-206

Guerrero M., Stewart R. D., Wang J. Z., Li X. A. (2002): Equivalence of the linear-quadratic and two-lesion kinetic models. Phys. Med. Biol. 47, 3197-3209 http://dx.doi.org/10.1088/0031-9155/47/17/310

Gustin J. P., Karakas B., Weiss M. B., Abukhdeir A. M., Lauring J., Garay J. P., Cosgrove D., Tamaki A., Konishi H., Konishi Y., Mohseni M., Wang G., Rosen D. M., Denmeade S. R., Higgins M. J., Vitolo M. I., Bachman K. E., Park B. H. (2009): Knockin of mutant PIK3CA activates multiple oncogenic pathways. Proc. Natl. Acad. Sci. U.S.A. 106, 2835-2840 http://dx.doi.org/10.1073/pnas.0813351106

Haince J. F., McDonald D., Rodrigue A., Dery U., Masson J. Y., Hendzel M. J., Poirier G. G. (2008): PARP1-dependent kinetics of recruitment of MRE11 and NBS1 proteins to multiple DNA damage sites. J. Biol. Chem. 283, 1197-1208 http://dx.doi.org/10.1074/jbc.M706734200

Higgins M. J., Beaver J. A., Wong H. Y., Gustin J. P., Lauring J. D., Garay J. P., Konishi H., Mohseni M., Wang G. M., Cidado J., Jelovac D., Cosgrove D. P., Tamaki A., Abukhdeir A. M., Park B. H. (2011): PIK3CA mutations and EGFR overexpression predict for lithium sensitivity in human breast epithelial cells. Cancer Biol. Ther. 11, 358-367 http://dx.doi.org/10.4161/cbt.11.3.14227

Huang J., Dynan W. S. (2002): Reconstitution of the mammalian DNA double-strand break end-joining reaction reveals a requirement for an Mre11/Rad50/NBS1-containing fraction. Nucleic Acids Res. 30, 667-674 http://dx.doi.org/10.1093/nar/30.3.667

Kaufmann L., Marinescu G., Nazarenko I., Thiele W., Oberle C., Sleeman J., Blattner C. (2011): $\mathrm{LiCl}$ induces TNF-alpha and FasL production, thereby stimulating apoptosis in cancer cells. Cell Commun. Signal. 9, 15 http://dx.doi.org/10.1186/1478-811X-9-15

Kumaravel T. S., Jha A. N. (2006): Reliable Comet assay measurements for detecting DNA damage induced by ionising radiation and chemicals. Mutat. Res. 605, 7-16 http://dx.doi.org/10.1016/j.mrgentox.2006.03.002

Lango M. N., Dyer K. F., Lui V. W., Gooding W. E., Gubish C., Siegfried J. M., Grandis J. R. (2002): Gastrin-releasing peptide 
receptor-mediated autocrine growth in squamous cell carcinoma of the head and neck. J. Natl. Cancer Inst. 94, 375-383 http://dx.doi.org/10.1093/jnci/94.5.375

Limbo O., Chahwan C., Yamada Y., de Bruin R. A., Wittenberg C., Russell P. (2007): Ctp1 is a cell-cycle-regulated protein that functions with Mre11 complex to control double-strand break repair by homologous recombination. Mol. Cell 28, 134-146 http://dx.doi.org/10.1016/j.molcel.2007.09.009

Liu C., Li Y., Semenov M., Han C., Baeg G. H., Tan Y., Zhang Z., Lin X., He X. (2002): Control of beta-catenin phosphorylation/degradation by a dual-kinase mechanism. Cell 108, 837-847 http://dx.doi.org/10.1016/S0092-8674(02)00685-2

McGinty E. E., Zhang Y., Guallar E., Ford D. E., Steinwachs D., Dixon L. B., Keating N. L., Daumit G. L. (2012): Cancer incidence in a sample of Maryland residents with serious mental illness. Psychiatr. Serv. 63, 714-717 http://dx.doi.org/10.1176/appi.ps.201100169

Mosmann T. (1983): Rapid colorimetric assay for cellular growth and survival: application to proliferation and cytotoxicity assays. J. Immunol. Methods 65, 55-63 http://dx.doi.org/10.1016/0022-1759(83)90303-4

Quiroz J. A., Gould T. D., Manji H. K. (2004): Molecular effects of lithium. Mol. Interv. 4, 259-272 http://dx.doi.org/10.1124/mi.4.5.6

Rass E., Grabarz A., Plo I., Gautier J., Bertrand P., Lopez B. S. (2009): Role of Mre11 in chromosomal nonhomologous end joining in mammalian cells. Nat. Struct. Mol. Biol. 16, 819-824 http://dx.doi.org/10.1038/nsmb.1641

Reynolds P., Anderson J. A., Harper J. V., Hill M. A., Botchway S. W., Parker A. W., O'Neill P. (2012): The dynamics of Ku70/80 and DNA-PKcs at DSBs induced by ionizing radiation is dependent on the complexity of damage. Nucleic Acids Res. 40, 10821-10831 http://dx.doi.org/10.1093/nar/gks879

Riballo E., Kuhne M., Rief N., Doherty A., Smith G. C., Recio M. J., Reis C., Dahm K., Fricke A., Krempler A., Parker A. R., Jackson S. P., Gennery A., Jeggo P. A., Lobrich M. (2004): A pathway of double-strand break rejoining dependent upon ATM, Artemis, and proteins locating to gamma-H2AX foci. Mol. Cell 16, 715-724 http://dx.doi.org/10.1016/j.molcel.2004.10.029

Salmanian S., Najafi S. M., Rafipour M., Arjomand M. R., Shahheydari H., Ansari S., Kashkooli L., Rasouli S. J., Jazi M. S., Minaei T. (2010): Regulation of GSK-3beta and beta-Catenin by Galphaq in HEK293T cells. Biochem. Biophys. Res. Commun. 395, 577-582 http://dx.doi.org/10.1016/j.bbrc.2010.04.087

Siles E., Villalobos M., Valenzuela M. T., Nunez M. I., Gordon A., McMillan T. J., Pedraza V., Ruiz de Almodovar J. M. (1996): Relationship between $\mathrm{p} 53$ status and radiosensitivity in human tumour cell lines. Br. J. Cancer 73, 581-588 http://dx.doi.org/10.1038/bjc.1996.101

Singh N. P., McCoy M. T., Tice R. R., Schneider E. L. (1988): A simple technique for quantitation of low levels of DNA damage in individual cells. Exp. Cell Res. 175, 184-191 http://dx.doi.org/10.1016/0014-4827(88)90265-0

Stewart G. S., Maser R. S., Stankovic T., Bressan D. A., Kaplan M. I., Jaspers N. G., Raams A., Byrd P. J., Petrini J. H., Taylor A.
M. (1999): The DNA double-strand break repair gene hMRE11 is mutated in individuals with an ataxia-telangiectasia-like disorder. Cell 99, 577-587

http://dx.doi.org/10.1016/S0092-8674(00)81547-0

Stewart R. D. (2001): Two-lesion kinetic model of double-strand break rejoining and cell killing. Radiat. Res. 156, 365-378 http://dx.doi.org/10.1667/0033-7587(2001)156[0365: TLKMOD]2.0.CO;2

Stracker T. H., Petrini J. H. (2011): The MRE11 complex: starting from the ends. Nat. Rev. Mol. Cell Biol. 12, 90-103 http://dx.doi.org/10.1038/nrm3047

Takemura H., Rao V. A., Sordet O., Furuta T., Miao Z. H., Meng L., Zhang H., Pommier Y. (2006): Defective Mre11-dependent activation of Chk 2 by ataxia telangiectasia mutated in colorectal carcinoma cells in response to replication-dependent DNA double strand breaks. J. Biol. Chem. 281, 30814-30823 http://dx.doi.org/10.1074/jbc.M603747200

Williams R. S., Moncalian G., Williams J. S., Yamada Y., Limbo O., Shin D. S., Groocock L. M., Cahill D., Hitomi C., Guenther G., Moiani D., Carney J. P., Russell P., Tainer J. A. (2008): Mre11 dimers coordinate DNA end bridging and nuclease processing in double-strand-break repair. Cell 135, 97-109 http://dx.doi.org/10.1016/j.cell.2008.08.017

Xie A., Kwok A., Scully R. (2009): Role of mammalian Mre11 in classical and alternative nonhomologous end joining. Nat. Struct. Mol. Biol. 16, 814-818 http://dx.doi.org/10.1038/nsmb.1640

Yamaguchi-Iwai Y., Sonoda E., Sasaki M. S., Morrison C., Haraguchi T., Hiraoka Y., Yamashita Y. M., Yagi T., Takata M., Price C., Kakazu N., Takeda S. (1999): Mre11 is essential for the maintenance of chromosomal DNA in vertebrate cells. EMBO J. 18, 6619-6629 http://dx.doi.org/10.1093/emboj/18.23.6619

Yang E. S., Wang H., Jiang G., Nowsheen S., Fu A., Hallahan D. E., Xia F. (2009): Lithium-mediated protection of hippocampal cells involves enhancement of DNA-PK-dependent repair in mice. J. Clin. Invest. 119, 1124-1135

http://dx.doi.org/10.1172/JCI34051

Yazlovitskaya E. M., Edwards E., Thotala D., Fu A., Osusky K. L., Whetsell W. O., Jr., Boone B., Shinohara E. T., Hallahan D. E. (2006): Lithium treatment prevents neurocognitive deficit resulting from cranial irradiation. Cancer Res. 66, 11179-11186

http://dx.doi.org/10.1158/0008-5472.CAN-06-2740

Ye J., Coulouris G., Zaretskaya I., Cutcutache I., Rozen S., Madden T. L. (2012): Primer-BLAST: a tool to design target-specific primers for polymerase chain reaction. BMC Bioinformatics 13, 134 http://dx.doi.org/10.1186/1471-2105-13-134

Yuan S. S., Hou M. F., Hsieh Y. C., Huang C. Y., Lee Y. C., Chen Y. J., Lo S. (2012): Role of MRE11 in Cell Proliferation, Tumor Invasion, and DNA Repair in Breast Cancer. J. Natl. Cancer Inst. 104, 1485-1502 http://dx.doi.org/10.1093/jnci/djs355

Received: July 20, 2013

Final version accepted: November 11, 2013 